\title{
Taxonomic notes on the genus Pseudodynerus (Hymenoptera, Vespidae, Eumeninae)
}

\author{
Marcel G. Hermes ${ }^{1}$, Bolivar R. Garcete-Barrett ${ }^{2}$ \& Andreas Köhler $^{1}$
}

1. Laboratório de Entomologia, Departamento de Biologia, Universidade de Santa Cruz do Sul, Av. Independência, 2293, Bairro Universitário, 96815-900 Santa Cruz do Sul, RS, Brasil.

2. Museo Nacional de Historia Natural del Paraguay, Sucursal 1, Campus Universidade Nacional de Asunción, 2169 CDP, Central XI, San Lorenzo, Paraguay.

ABSTRACT. The differences between Pseudodynerus auratoides (Bertoni, 1918) and Pseudodynerus serratus (Fox, 1902) are established. Lectotypes of Stenodynerus mondaiensis Bertoni, 1918 and Stenodynerus auratoides Bertoni, 1918 are designated. Pseudodynerus penicillatus (Zavattari, 1912) is redescribed and newly raised from synonymy under P. serratus (Fox, 1902).

KEYWORDS. Eumeninae, Pseudodynerus, lectotype, designation, redescription.

RESUMO. Notas taxonômicas sobre o gênero Pseudodynerus (Hymenoptera, Vespidae, Eumeninae). As diferenças entre Pseudodynerus auratoides (Bertoni, 1918) e Pseudodynerus serratus (Fox, 1902) são estabelecidas. Lectótipos são designados para Stenodynerus mondaiensis Bertoni, 1918 e Stenodynerus auratoides Bertoni, 1918. Pseudodynerus penicillatus (Zavattari, 1912) é redescrita e revalidada.

PAlaVRas-ChaVE. Eumeninae, Pseudodynerus, lectótipo, designação, redescrição.

Among the Neotropical Vespidae, one of the most common mimicry complexes is the one that follows the epiponine Brachygastra lecheguana (Latreille, 1824) coloration pattern. GARCETE-BARRETT (1999) provided a partial list of eight species of the subfamily Eumeninae from Paraguay that belong to this complex, including $P$. serratus (Fox, 1902) and P. auratoides (Bertoni, 1918), which are distinguished by the shape of the metanotum, according BERTONI (1918a) and BEQUAERT (1941).

The material examined is from Bertoni's collection, currently deposited at the Museo Nacional de Historia Natural del Paraguay, from the American Museum of Natural History and the Carnegie Museum of Natural History. In addition, some specimens recently collected in Paraguay and Southern Brazil were studied, showing no significant differences between these two species regarding the shape of the metanotum. However, other well-marked and constant structural differences allow ready separation of these two species.

Odynerus penicillatus Zavattari, 1912 was described based on a single female from French Guiana, and reduced to a variety (recently treated as synonymy) of P. serratus by BEQUAERT (1941) (also new generic placement by Bequaert). However, this author did not examined the primary type of $O$. penicillatus, basing the synonymy only on Zavattari's original description. Some taxonomic notes on this taxon are presented herein, and $P$. penicillatus is newly raised from synonymy under $P$. serratus.

The depository institutions of the examined material are: AMNH, American Museum of Natural History, New York, United States of America; CMNH, Carnegie Museum of Natural History, Pittsburgh, United States of America; SMB, Zoologisches Museum an der Humbolt-Universität zu Berlin, Berlin, Germany; IBNP, Museo Nacional de Historia Natural del Paraguay, San Lorenzo, Paraguay;
CESC, Coleção Entomológica da Universidade de Santa Cruz do Sul, Santa Cruz do Sul, Brazil.

The terminology used herein follows CARPENTER \& Garcete-Barrett (2002) and CARPENTER (2004).

\section{Pseudodynerus auratoides (Bertoni, 1918) (Figs. 1-9)}

Stenodynerus auratoides BERTONI, 1918a:201, female, male Paraguay: "Pto. Bertoni" (IBNP, Col. Bertoni). Lectotype female by present designation.

Odynerus (Stenodynerus) auratoides; BERTONI, 1918b:207 (distr.). Pseudodynerus auratoides; BEQUAERT, 1941:7 (distr.).

Material examined. PARAGUAY, Alto Paraná: Puerto Bertoni, \&, XII.1911, A. W. Bertoni col. (IBNP E.9), lectotype by present designation; 8 \&, $2 \circlearrowleft$ (IBNP E.5, E.43, E.45, E.44, E.10, B75, B.76, B.77, E.82, E.83), ditto, paralectotypes. BRAZIL, Paraná: Prudentópolis, đ゙, 23-25.II.1969, C. Porter \& A. Garcia col. (AMNH); Rio Grande do Sul: Santa Cruz do Sul, †, 2 ๑, 23-30.I.2002, D. J. Krise col. (CESC 2303, 2310, 2181); same data but: local 03, 23.I.2002; o', 23.X.2001, D. J. Krise col. (CESC 639); 2 \&, 29.IV.2004, M. G. Hermes col. (CESC 9573, 9574).

BERTONI (1918a) mentioned having collected this species visiting flowering plants of the family Asteraceae. The specimens from Brazil were collected from 11 am to 2 pm on inflorescences of Eryngium horridum Malme (Apiaceae), and flowers of Sida rhombifolia L. (Malvaceae), Verbena bonariensis L. (Verbenaceae) and Trema micrantha (L.) Blume (Ulmaceae).

\section{Pseudodynerus serratus (Fox, 1902) (Figs. 10-19)}

Odynerus serratus Fox, 1902:65, 69 (key), male "Brazil: Corumbá" [CMNH, examined];

Odynerus (Ancistrocerus) serratus; DALLA TORRE, 1904:54 (cat.); BRÈTHES, 1906:360, fig. 34 (male, distr.). 

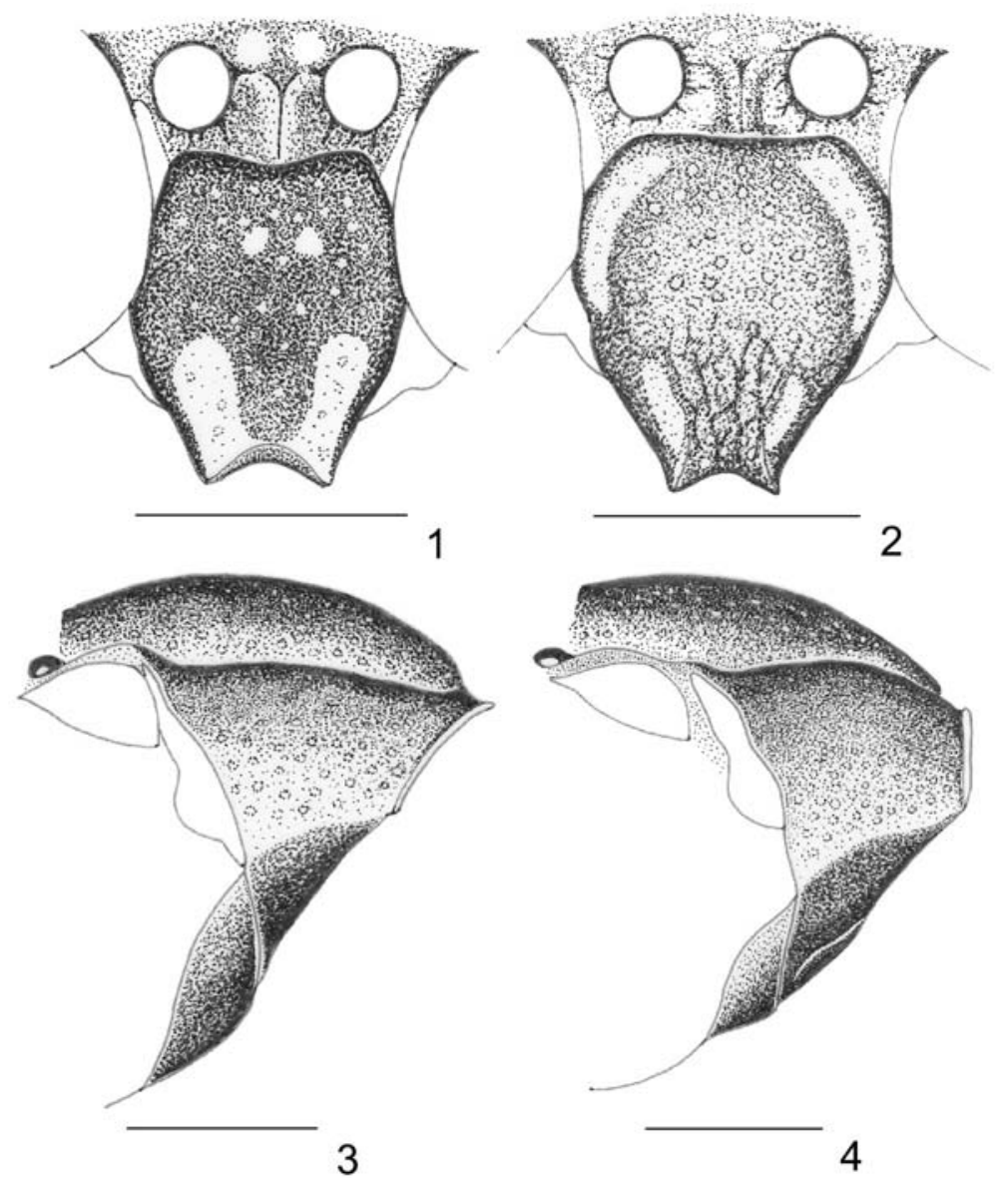

Figs. 1-4. Pseudodynerus auratoides (Bertoni, 1918): 1, male clypeus; 2, female clypeus; 3, male pronotum; 4, female pronotum. Scale bars, $1 \mathrm{~mm}$.

Odynerus (Stenodynerus) serratus; BERTONI, 1918b:207 (cat.); CARPENTER \& VAN DER Vecht, 1991:238 (cat.).

Odynerus (Stenancistrocerus) serratus; BeRTONI, 1918b:208 (cat.) Stenodynerus serratus; BERTONI, 1918a:192, 202 (distr.).

Stenodynerus mondaiensis Bertoni, 1918a:200, female, male "Paraguay: Pto. Bertoni" (IBNP, Col. Bertoni). Lectotype female by present designation.

Odynerus (Stenodynerus) mondaiensis; BeRTONI, 1918b:207 (cat.). Pseudodynerus serratus; Bequaert, 1941:2 (key), 6 (female, distr.).

Pseudodynerus serratus var. mondaiensis; BeQuaERT, 1941:7 (probably identical to typical $P$. serratus).

Pseudodynerus serratus var. penicillatus; BEQUAERT, 1941:7 (key).

Material examined. PARAgUAY, Alto Paraná: Puerto Bertoni, f, XII.1911, A. W. Bertoni col. (IBNP E.21, labeled "Tipo") Lectotype of Stenodynerus mondaiensis Bertoni by present designation; O', I.1909, A. W. Bertoni col. (IBNP E.77); \&, 30.X.1919, A. W. Bertoni col. (IBNP E.76); †, II.1919, A. W. Bertoni col. (IBNP E.42); 2 \%, II.1919, A. W. Bertoni col. (IBNP E.26, C.47); 2 o', III.1919, A. W. Bertoni col. (IBNP E.23, E.29); 2 \%, O, X.1919, A. W. Bertoni col. (IBNP E.28, E.33, C.50); 2 \&, 3 o, A. W. Bertoni col. (IBNP B.60, B.72, E.22, E.78, E.27); 3 \&, XII.1911, A. W. Bertoni col. (IBNP E.31, E.24, E.25 bearing the label "cotipos" "a" "b" "c" of Stenodynerus mondaiensis Bertoni); Paraguarí: Parque Nacional Ybycuí, \&, 15.II.1999, B. Garcete col. (IBNP); \&, 13-18.XII.1989, M. Cooper col. (IBNP); Naranjo, \&, 3-8.II.1996, B. Garcete col. (IBNP); Cordillera: San Bernardino, ơ, 5-6.IV.1997, B. Garcete col. (IBNP); Capital: Jardín Botánico, \&, 11.IV.1999, B. Garcete col. (IBNP); Canindeyú: Reserva Natural del Bosque Mbaracayú, đ', 14.I.1997, B. Garcete col. (IBNP); Concepción: Colonia Ypané, \&, 26.II.1997, B. Garcete col. (IBNP); ơ, 27.II.1997, B. Garcete col. (IBNP); đ̛, 28.II.1997, B. Garcete col. (IBNP); †,
1.III.1997, B. Garcete col. (IBNP); San Pedro: Rio Ypane, 3 \%, XI-XII.1983, M. A. Fritz col. (AMNH); ơ, II.1979, M. A. Fritz col. (AMNH); Without locality or collector, 2 \&, o, X.1919 (IBNP B.71, E.38, B.73).

BERTONI (1918a) mentioned having collected this species visiting flowering plants of the family Asteraceae. One of the specimens collected in Colonia Ypané was captured while collecting mud on a path inside the woods.

Remarks. As mentioned above, the shape of the metanotum is not to be considered a distinguishable character for the species $P$. auratoides and $P$. serratus, as stated by Bertoni (1918a) and BequaERT (1941). However, some other structural features allow ready separation of these two taxa, such as the apex of the clypeus. In $P$. auratoides males, it is slightly concave with a translucent apical margin (fig. 1), and its apical teeth are slightly prominent in the females (fig. 2). In males of $P$. serratus, the clypeus is distinctly concave and without a translucent apical margin (fig. 10), and its apical teeth are more prominent in the females (fig. $11)$. The lateral face of pronotum of $P$. auratoides is slightly concave, separated from the dorsal face by a very weak blunt projection, especially weak in the females, somewhat evident in oblique antero-lateral upper view (figs. 3, 4). On the contrary, the lateral face of pronotum of $P$. serratus is distinctly concave, separated from the dorsal face by a well-defined blunt 

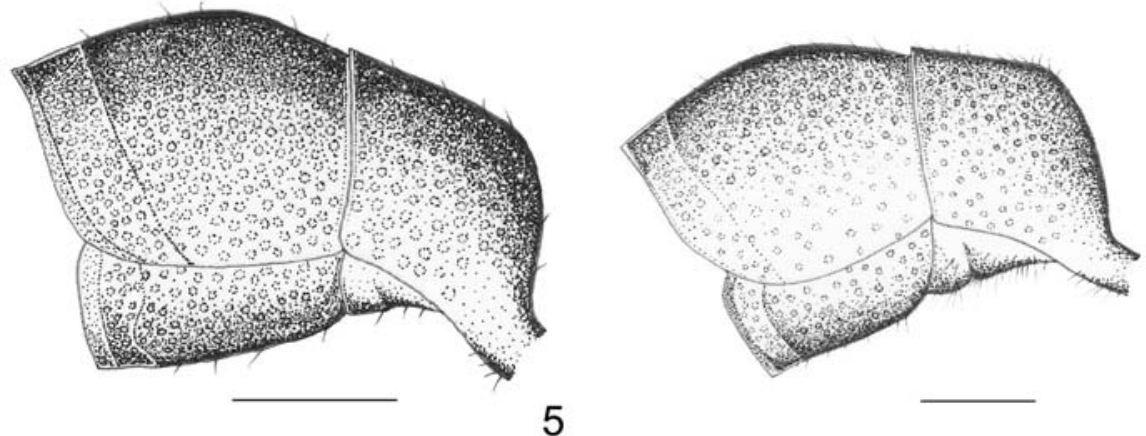

5
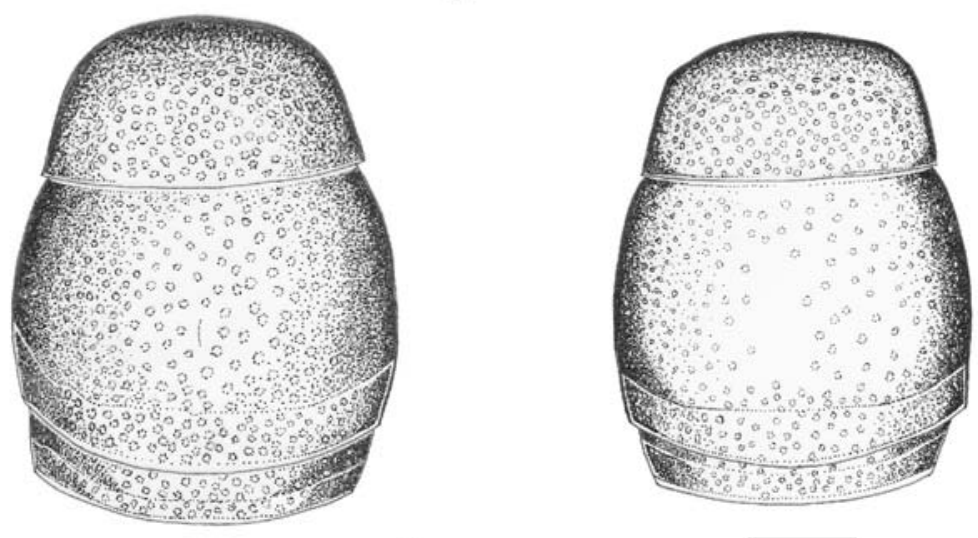

7

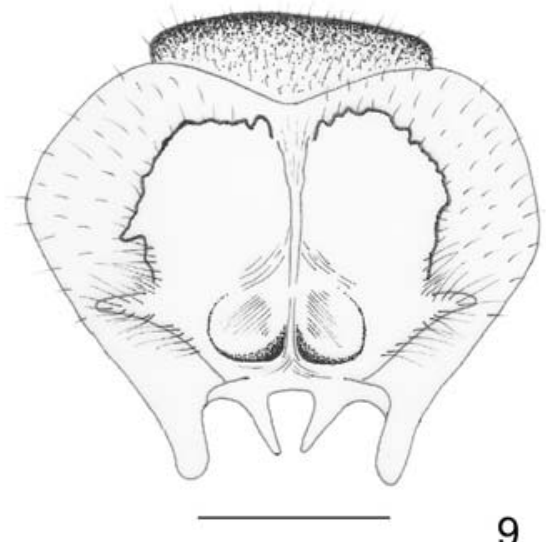

Figs. 5-9. Pseudodynerus auratoides (Bertoni, 1918): 5, male terga I-II in lateral view; 6, female terga I-II in lateral view; 7, male terga I-III in dorsal view; 8, female terga I-III in dorsal view; 9, female posterior face of propodeum. Scale bars, 1 mm.

projection, even in the females, evident in oblique anterolateral upper view (figs. 12, 13). Another feature that allow separation between these species is the hump of tergum II, which is almost obsolete in females and somewhat produced, slightly prominent in profile on males of $P$. auratoides (figs. 5, 6). The hump of tergum II is welldefined in females and distinctly produced in profile on males of $P$. serratus (figs. 14, 15). Finally, the terga II and III of $P$. auratoides bear apical bands formed by large macropunctures, which are of uniform density and coarseness on most of their length (figs. 7, 8). These apical bands are formed by large and dense macropunctures in $P$. serratus, which are denser and coarser at its center in dorsal view, especially in males, in which the macropunctures may be almost confluent (figs. 16, 17).

\section{Pseudodynerus penicillatus (Zavattari, 1912) \\ (Figs. 20-25)}

Odynerus penicillatus ZavatTARI, 1912:238 (key), 240, female (in subgenus Leionotus, division Pseudodynerus) - "Franz. Guyana: Cayenne" (Berlin) [type examined].

Pseudodynerus serratus var. penicillatus BEQUAERT, 1941:7 (key).

Diagnosis. Pseudodynerus penicillatus (Zavattari, 1912) belongs to the group of species that have a distinct hump on the second tergum, and is closely related to $P$. serratus (Fox, 1902) and P. auratoides (Bertoni, 1918). Differently from these, the lateral face of the pronotum is almost flat in oblique antero-lateral upper view, separated from the dorsal face by a very weak blunt projection (fig. 20). Postero-lateral angles of propodeum rounded (fig. 21), dorsal face not separated from lateral face by a blunt 

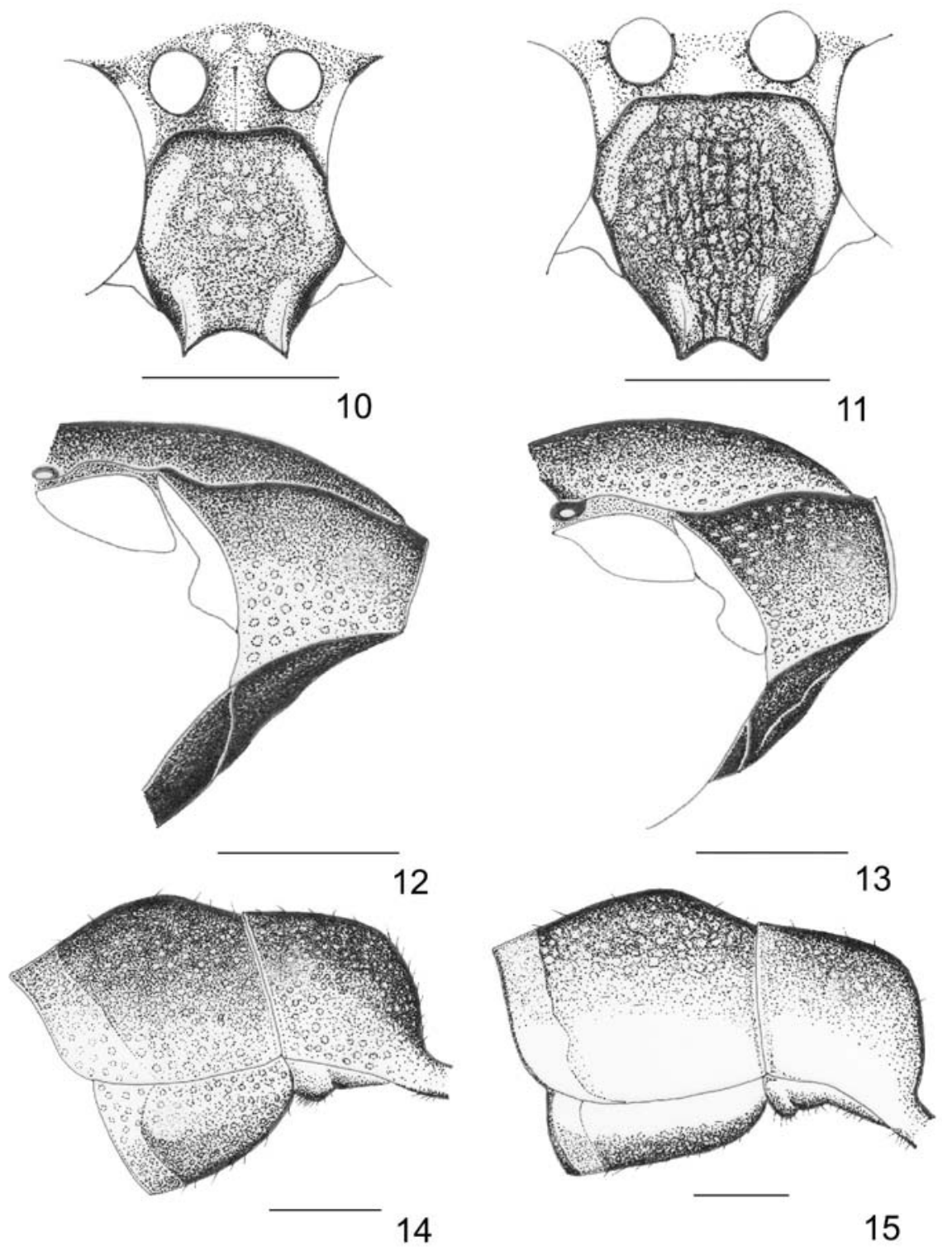

14

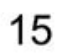

Figs. 10-15. Pseudodynerus serratus (Fox, 1902): 10, male clypeus; 11, female clypeus; 12, male pronotum; 13, female pronotum; 14 , male terga I-II in lateral view; 15 , female terga I-II in lateral view. Scale bars, $1 \mathrm{~mm}$.

projection as in $P$. serratus. The propodeal lamellae are complete and reach the postero-lateral angles of the propodeum. This feature seems to be variable in $P$. serratus, whereas in $P$. auratoides the propodeal lamellae are short and do not reach the postero-lateral angles of the propodeum (figs. 9, 18). The hump of the second tergum is much less raised in profile than in $P$. serratus (fig. 22). The mesopleura have much longer and erect whitish hairs than in the two other mentioned species. The metasomal segments are entirely black, without yellow bands on terga II to VI in females as in P. serratus and $P$. auratoides. Punctures on the apical third of the second tergum are a little coarser than those of the rest of tergum, but not as coarse and confluent as in P. serratus (fig. 23). The propodeal valvulae are elongated in profile, extending forward and surpassing the level of the hind coxae (fig. 25), while it is short and more rounded, not surpassing the level of the hind coxae in $P$. serratus (fig.
19). Female clypeus with coarser macropunctures than in $P$. auratoides and $P$. serratus (fig. 24). The characters used to delimit species were constant in all examined specimens.

Description. Forewing length $11.8 \mathrm{~mm}$. Female black. Yellow markings as follows: bands on lateral margins of clypeus; bands on internal upper margins of mandibles; spots between antennal sockets; small bands on inner and outer bases of orbital margins; band on scape beneath; bands on anterior face of fore tibiae; thin bands on basal margin of metanotum. Light brown markings as follows: inner face of flagelomeres; outer margin and center of tegulae. Legs brownish black, except for the last tarsal segments that are testaceous brown. Margins of posterior face of propodeum whitish yellow. Forewings infuscated, costal region blackish. Venation black.

Head coarsely punctate on frons and vertex, less coarsely punctate on genae; region behind occeli with 


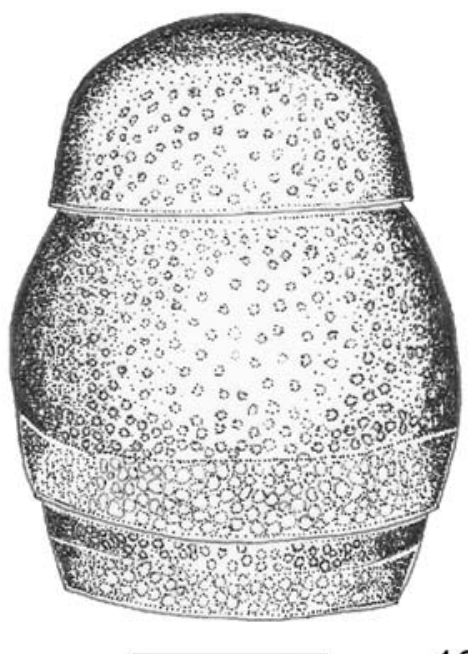

16

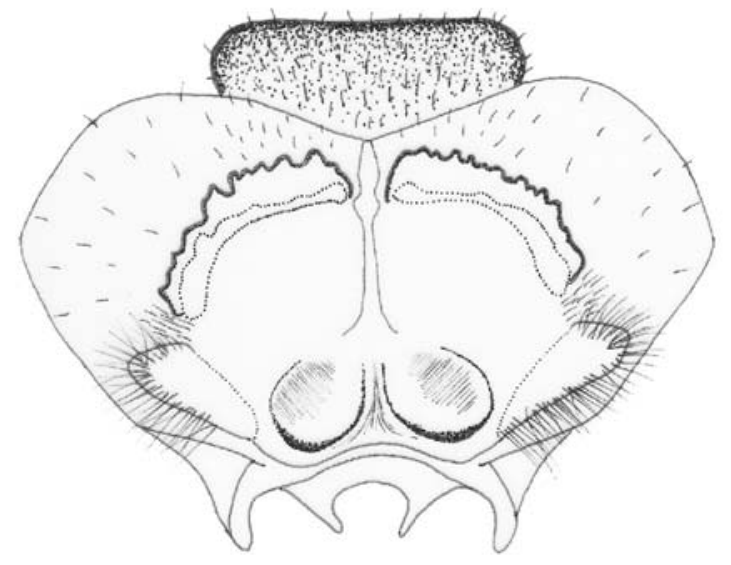

18

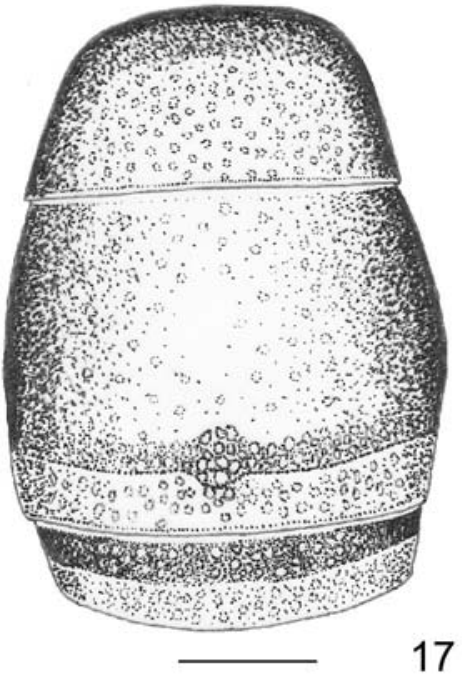

17

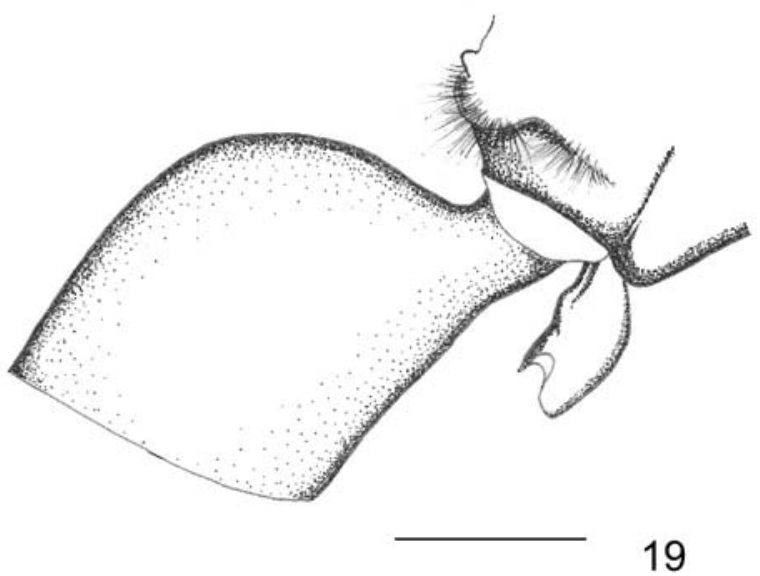

Figs. 16-19. Pseudodynerus serratus (Fox, 1902): 16, male terga I-III in dorsal view; 17, female terga I-III in dorsal view; 18, female posterior face of propodeum; 19, female propodeal valvula. Scale bars, $1 \mathrm{~mm}$.

two patches formed by erect brownish black hairs; clypeus as long as wide, strongly punctate on upper half and sides, striatopunctate on inferior half; apical teeth of clypeus slightly carinate; region between antennal sockets longitudinally ridged right above clypeus, preceded by a well-developed stretched out sulcus; occipital carina strongly developed, almost lameliform dorsally.

Thorax elongate, almost flat in profile, with somewhat long and erect whitish hairs, except for the mesopleura where the hairs are much longer; pronotum coarsely punctate, lateral face almost flat, separated from dorsal face by a very weak blunt projection; humeral angles distinct; lateral face of mesopleura striatopunctate on superior third, coarsely punctate below, anterior face impunctate and posterior face punctate only on superior half; mesoscutum coarsely punctate, with a median anterior longitudinal thin line, region near tegulae micropunctate; tegulae with somewhat distinct punctation on inner margin adjacent to mesoscutum; scutellum less coarsely punctate than mesoscutum, with somewhat distinct micropunctures between macropunctures; metanotum triangular, macropunctures as in the scutellum, micropunctures indistinct; dorsal face of propodeum coarsely punctate, lateral face less coarsely punctate; metapleura impunctate; lateral angles of propodeum rounded when seen from behind, dorsal face not separated from the lateral face by a distinct blunt projection; posterior face of propodeum concave, smooth and shiny on superior half, with oblique transversal striae on inferior half, divided by a deep median furrow on superior two thirds; inferior one third of posterior face of propodeum with two deep concavities divided by a central well-developed ridge; upper propodeal lamella reaching postero-lateral angles of propodeum; lower propodeal lamella strongly pointed, laterally forming a developed projection directed outwards; lateral faces of propodeum covered by a whitish pubescence, inferior propodeal lamella covered with long and erect whitish hairs; all tibiae and tarsi strongly haired.

Metasomal segments with somewhat long and erect whitish yellow hairs, especially longer on apical portion of sterna II-V and terga II-VI; tergum I very sparsely 


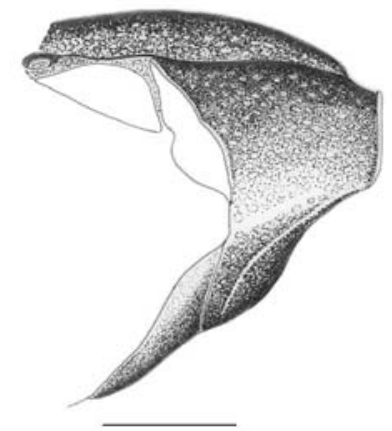

20

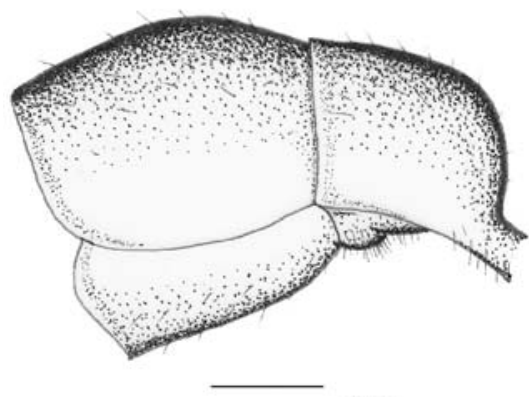

22

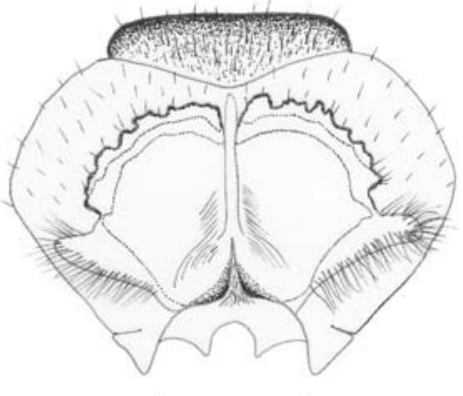

21

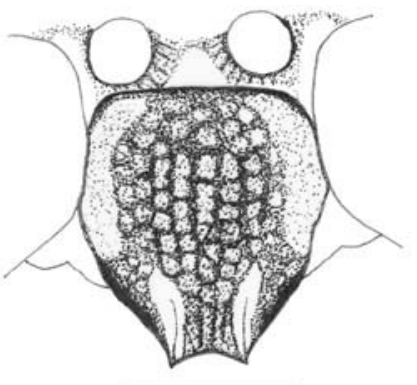

24

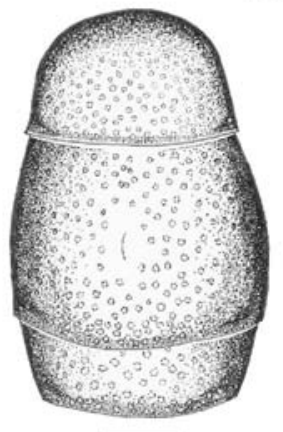

23

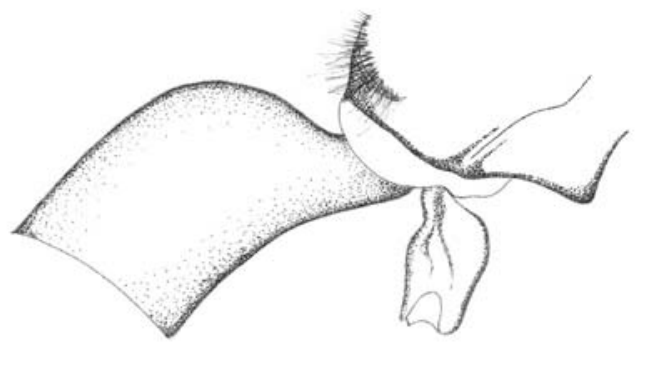

25

Figs. 20-25. Pseudodynerus penicillatus (Zavattari, 1912): 20, female pronotum; 21, female posterior face of propodeum; 22, female terga I-II in lateral view; 23, female terga I-III in dorsal view; 24, female clypeus; 25 , female propodeal valvula. Scale bars, 1 mm.

punctate on anterior declivity, the punctures becoming closer on area behind anterior declivity, but distance between punctures almost two times its diameter, space among punctures filled with closely reticulate micropunctation; second tergum with a weak hump dorsally, almost convex in profile, and with closely macropunctation that becomes closer and coarser on apical third; terga III-V closely punctate, space among punctures lesser than its diameter; tergum VI with very sparce punctures; sterna II-V with somewhat sparce macropunctures, space between punctures greater than its diameter.

Material examined. FRENCH GUYANE, Cayenne: $q$ [type], without date or collector (SMB). GUYANE, Matoury: , 22.IX.1996, J. Wenzel \& J. M. Carpenter cols. (AMNH).

Comments. While studying a collection of eumenine wasps deposited in the American Museum of Natural History, we discovered an additional specimen of $P$. penicillatus collected in Guyane on September 1996. This specimen is much well-preserved than the one described by Zavattari in 1912, what allowed a better observation of the coloration of this species. Besides, this discovery supports the validation of this taxon, previously believed to be a variation of $P$. serratus. Yet, $P$. penicillatus remains known only by two females from Northern South America, and male unknown. While it was considered to be a synonym for $P$. serratus, its geographic distribution would not provide much information on species taxonomy, although $P$. serratus was only known from Paraguay and central Brazil. Field work is urgently needed to clarify the limits between species in this complex genus of eumenine wasps.

Acknowledgments. We thank James M. Carpenter for specimens loan and critical suggestions on earlier versions of the manuscript, Frank Koch and John Rawlins for type specimens loaning, and Gabriel A. R. Melo for suggestions on the use of the ICZN terms. 


\section{REFERENCES}

Bequaert, J. 1941. Pseudodynerus, a neotropical complex of eumenine wasps (Hymenoptera, Vespidae). American Museum Novitates 1106:1-10.

Bertoni, A. W. 1918a. Contribución al conocimiento de los himenópteros diplópteros americanos (especies y nidos nuevos o poco conocidos). Anales Científicos Paraguayos 2(3):184-202.

1918b. Catálogo de los véspidos sociales y solitarios del Paraguay. Anales Científicos Paraguayos 2(3):203-208. Brèthes, J. 1906. Véspidos y Euménidos Sudamericanos. Anales del Museo Nacional de Buenos Aires 13:311-377.

Carpenter, J. M. 2004. Ancistroceroides de Saussure, a potter wasp genus new for the United Status, with a new key to the genera of Eumeninae of America north of Mexico (Hymenoptera: Vespidae). Journal of the Kansas Entomological Society 77(4):721-741.

Carpenter, J. M. \& Garcete-Barrett, B. R. 2002. A key to the neotropical genera of Eumeninae (Hymenoptera: Vespidae). Boletín del Museo Nacional de Historia Natural del Paraguay 14(1-2):52-73.

Carpenter, J. M. \& van der Vecht, J. 1991. A study of the Vespidae described by William J. Fox (Insecta: Hymenoptera), with assessment of taxonomic implications. Annals of the Carnegie Museum 60(3):211-241.

Dalla Torre, K. W. 1904. Vespidae. Genera Insectorum 19: $1-108$.

Fox, W. J. 1902. Contributions to a knowledge of the Hymenoptera of Brazil, $N^{\circ}$. 8.- Eumenidae, continued (Genus Odynerus). Proceedings of the Academy of Natural Sciences of Philadelphia 1902:44-69.

Garcete-Barrett, B. R. 1999. Guía ilustrada de las avispas sociales del Paraguay (Hymenoptera: Vespidae: Polistinae). London, The Natural History Museum. 44p.

Zavattari, E. 1912. Materialien für eine Monographie der Neotropischen Eumeniden. Archiv für Naturgeschichte 78(Abteilung A)4:1-272.

Recebido em novembro de 2004. Aceito em maio de 2005. ISSN 0073-4721

Artigo disponível em: www.scielo.br/isz 